Volume 6 Nomor 1, Februari 2021, halaman 13 - 32.

\title{
Peningkatan Minat Dan Hasil Belajar Matematika Siswa dengan Penggunaan Model Pembelajaran Kooperatif Tipe Sudent Teams Achievement Division
}

\author{
Increasing Student Interest And Learning Outcomes with The Use Of \\ The Student Teams Achievement Division Cooperative Learning Model
}

\author{
Hanifatul Rahmi \\ Sekolah Tinggi Teknik (STT) Dumai, Jalan Utama Karya Bukit Batrem Kota Dumai \\ Email: hanifatulrahmi@sttdumai.ac.id
}

\begin{abstract}
ABSTRAK
Rendahnya minat dan hasil belajar matematika siswa perlu diatasi sejak dini. Artikel ini merupakan penelitian tindakan kelas dengan dua Siklus yang bertujuan untuk meningkatkan minat dan hasil belajar siswa Kelas III pada salah satu Sekolah Dasar di Kecamatan Rimba Sekampung yang berjumlah 24 orang siswa dengan menerapkan model pembelajaran kooperatif tipe Student Teams Achievement Division (STAD) dalam materi perkalian dan pembagian. Adapun tahapan penelitian ini adalah perencanaan, tindakan, pengamatan, dan refleksi. Instrumen yang digunakan adalah tes hasil belajar, observasi dan kuesioner yang dianalisis secara kuantitatif dan kualitatif. Berdasarkan hasil analisis data diperoleh bahwa: (1) rata-rata minat belajar siswa pada Siklus I adalah 78,4 dengan kategori baik; (2) rata-rata minat belajar siswa pada Siklus II naik menjadi 84,9 dengan kategori baik; (3) rata-rata hasil belajar siswa pada Siklus I adalah 82,3 dengan persentase ketuntasan siswa 75,00\%; (4) rata-rata hasil belajar siswa pada Siklus II naik menjadi 86, 2 dengan persentase ketuntasan siswa 83,33\%. Kesimpulannya adalah model pembelajaran Student Teams Achievement Division (STAD) dapat meningkatkan minat dan hasil belajar siswa. Penelitian ini berimplikasi pada penelitian lain yang sejenis mengenai pentingnya peran Dosen Pendidikan Matematika dalam bertindak sebagai peneliti pada penelitian tindakan kelas di sekolah menengah.

Kata Kunci : Penelitian Tindakan Kelas, minat belajar, hasil belajar, STAD
\end{abstract}

\section{ABSTRACT}

The lowerness of students' mathematical learning interest and outcome need to be overcome early. This article was a classroom action research with two cycles which aims to improve the third grade students' mathematical learning interest and outcome at one of Elementary School in Rimba Sekampung districs total 24 students with applied the cooperative learning model type Student Teams Achievement Division (STAD) in multiplication and divition subjects. The research steps were planning, action, observation and reflection. The instruments that we used were the learning outcome tests, observation and questionnaire that were analyzed quantitatively and qualitatively. According to the data analysis results found that: (1) the average of student's learning interest at cycle I was 78,4 with good category; (2) the average of student's learning interest increased at cycle II was 84,9 with good category; (3) the average of student's learning outcome at cycle I was 82,3 with percentage of student completeness was $75,00 \%$; (4) the average of student's learning outcome at cycle II increased in 86,2 with percentage of student completeness was $83,33 \%$. The conclusion was Problem Based Learning Model can improve student's learning outcome. This study implicated another relevant studies about the importance of Mathematics Education Lecturer role in acting as the researcher in classroom action research.

Keyword(s): classroom action research, learning interest, learning outcome, STAD 


\section{How to Cite: Rahmi, H. (2021). Peningkatan Minat Dan Hasil Belajar Matematika Siswa dengan Penggunaan Model Pembelajaran Kooperatif Tipe Sudent Teams Achievement Division. Mathline: Jurnal Matematika dan Pendidikan Matematika, Vol. 6 No. 1, 13 - 32.}

DOI: $\underline{\text { https://doi.org/10.31943/mathline.v6i1.165 }}$

\section{PENDAHULUAN}

Pendidikan merupakan suatu proses perubahan sikap serta tingkah laku seseorang atau sekelompok orang sebagai usaha dalam pendewasakan manusia dengan upaya pengajaran dan pelatihan, prosedur, cara, perbuatan mendidik (Pendidikan \& Kebudayaan, 2002). Pendidikan memungkinkan kesempatan perkembangan dengan maksimal, mempelajari kejadian masa lalu, kesempatan aktif dan kreatif yaitu melalui pendidikan karakter serta tata laku yang intern (Hamalik, 2009). Matematika merupakan satu dari beberapa pendidikan yang mampu menumbuhkembangkan karakter siswa agar aktif dan kreatif.

Handayani, Nandang \& Lestari (2018) berpendapat yaitu Matematika adalah salah satu mata pelajaran yang berperan penting pada dunia pendidikan. Matematika merupakan mata pelajaran utama di satuan pendidikan yang berperan utama untuk membentuk kepribadian dan proses berpikir siswa. Matematika mampu menumbuhkengembangkan siswa berkepribadian baik seperti sabar, toleran dan bersemangat melalui kemampuan berpikir yang logis, sistematis dan terbuka. Konsep matematika tidak akan pernah terlepas dari aktivitas manusia dalam kehidupan sehari-hari. Susanto (2013) menyatakan bahwa matematika merupakan ilmu dasar yang sebaiknya dikuasai. Usia Sekolah Dasar (SD) merupakan masa kritis bagi seorang anak sehingga matematika penting diajarkan pada proses belajar-mengajar untuk usia tersebut. Kemampuan matematis menjadi kemampuan yang sangat penting untuk dimiliki pada era globalisasi sekarang ini. Berdasarkan dua pendapat tersebut, peneliti menarik kesimpulan yaitu matematika adalah ilmu dasar yang penting untuk dimiliki siswa sejak usia dini.

Kompleksitas makna pembelajaran merupakan usaha sadar guru untuk membelajarkan siswanya (mengarahkan interaksi siswa melalui sumber belajar lainnya) guna mencapai tujuan yang diinginkan. Pembelajaran Matematika mencakup konsep abstrak yang penting untuk diterjemahkan menjadi konsep yang mudah dipahami oleh siswa. Angka dan sombol merupakan konsep utama yang terdapat pada matematika. Sementara itu, berhitung, ilmu ukur dan aljabar merupakan bahan kajian matematika yang 
bertujuan untuk pengembangan logika dan kemampuan berpikir siswa (PP No.32 Tahun 2013). Usaha pemahaman konsep dan materi matematika membutuhkan siswa yang aktif pada saat melakukan aktivitas pembelajaran. Oleh sebab itu, agar siswa menjadi lebih aktif maka diperluan adanya minat belajar.

Minat belajar memiliki pengaruh yang signifikan terhadap hasil belajar sebab dengan adanya minat, seseorang akan dengan senang hati mau melakukan sesuatu yang diminatinya. Pangestu, Samparadja, \& Tiya (2015) menyatakan bahwa minat belajar siswa memiliki pengaruh positif terhadap hasil belajar matematika. Sebaliknya, tanpa minat seseorang tidak akan mungkin mau melakukan sesuatu. Siswa akan menjadi lebih mudah memahami materi yang menarik minatnya. Nasution (2015) menyatakan bahwa rendahnya kemampuan pemahaman siswa juga berimplikasi pada rendahnya prestasi atau hasil belajar. Sejalan dengan itu, Lestari, Aisah, \& Nurafifah (2020) menyatakan bahwa hasil belajar merupakan salah satu indikator kemampuan pemahaman matematis siswa. Hasil belajar merupakan kemampuan yang diperoleh siswa setelah melalui aktivitas belajar (Nasution \& Lubis, 2019)

Menurut peneliti, minat belajar siswa merupakan hal yang sangat penting sebab tanpa adanya minat belajar, maka siswa tidak akan berhasil mencapai tujuan pembelajaran sehingga proses belajar-mengajar tidak akan berjalan lancar. Nasution (2016) juga menyatakan bahwa siswa seharusnya memiliki rasa ingin tahu, perhatian dan minat saat belajar Matematika. Jika siswa berminat dalam belajar Matematika, maka siswa akan belajar dengan sepenuh hati, bersungguh-sungguh, rajin, serta merasa senang mengikuti pembelajaran Matematika karena adanya daya tarik yang dirasakan oleh siswa saat belajar Matematika.

Slameto (2003) menyatakan bahwa siswa yang mempunyai minat belajar akan menunjukkan karakteristik yaitu: (1) memiliki kebiasaan yang konsisten dalam memperhatikan dan mengingat sesuatu yang dipelajarinya dengan terus-menerus, (2) adanya perasaan senang dan suka kepada sesuatu yang diminati, (3) memperoleh suatu kepuasan dan kebanggaan tersendiri kepada sesuatu yang diminati, (4) adanya perasaan terikat kepada suatu aktivitas yang diminati, (5) lebih suka sesuatu yang diminatinya. Winkel (2004) menyatakan ciri khas dari minat yaitu memiliki kecenderungan terhadap perasaan ketertarikan dan kesenangan kepada materi atau topik yang sedang dipelajarinya. Berdasarkan pendapat di atas, bisa diambil kesimpulan yaitu ciri khas minat belajar adalah adanya perhatian, perasana suka dan senang, serta adanya perasaan keterikatan terhadap aktivitas yang diminatinya. Dapat disimpulkan bahwa ciri khas minat belajar dibagi ke 
dalam empat indikator yaitu: (1) perasaan suka dan senang terhadap pembelajaran (kekompakan); (2) usaha untuk mengembangkan diri (partisipasi); (3) perhatian dalam pembelajaran (keaktifan); dan (4) keterlibatan dalam pembelajaran (tangging jawab).

Berdasarkan hasil observasi awal pada salah satu Sekolah Dasar (SD) di Kecamatan Rimba Sekampung diketahui bahwa siswa memiliki minat belajar matematika yang rendah terutama pada materi Perkalian dan Pembagian. Siswa sibuk sendiri saat pembelajaran bahkan mengobrol dengan teman di sebelahnya. Ada juga siswa yang tampak mengantuk selama proses pembelajaran. Siswa juga enggan bertanya terkait materi yang sedang diajarkan. Materi perkalian dan pembagian membutuhkan keterampilan dalam berhitung, berkonsentrasi, serta pengulangan berhitung yang mengakibatkan kemalasan pada diri siswa (Purwandari \& Wahyuningtyas, 2017).

Rendahnya minat belajar siswa tersebut mengakibatkan hasil belajar siswa yang rendah khususnya pada materi Perkalian dan Pembagian. Siswa cenderung menghafal materi tersebut tanpa memahami konsep dasar dari Perkalian dan Pembagian. Siswa juga terbiasa dengan rumus-rumus cara cepat memperoleh hasil Perkalian dan Pembagian tanpa disertai pemahaman yang benar. Hanya 13 siswa atau 54,17\% siswa yang tuntas dari jumlah siswa keseluruhannya yaitu 24 siswa dan rerata nilai mencapai 70,8. Hal tersebut menunjukkan bahwa hasil belajar yaitu ketercapaian kompetensi yang tertuang dalam skenario pembelajaran dan ketuntasan individu masih berada di bawah KKM klasikal yaitu $75 \%$.

Upaya untuk perbaikan dan peningkatan minat serta hasil belajar dilakukan melalui pemilihan model pembelajaran yang relevan. Salah satu model pembelajaran inovatif yang mampu mendorong siswa dalam peningkatan minat belajar serta pemahaman materi belajar siswa adalah pembelajaran koorperatif tipe Student Teams Achievement Division (STAD). Hosnan (2014) menyatakan bahwa model STAD termasuk salah satu pendekatan kontekstual dalam pembelajaran abad-21. STAD menekankan pada diskusi untuk memecahkan masalah. Hal tersebut bersesuaian dengan Esminarto, Sukowati, Suryowati, \& Anam (2016) yang menyatakan bahwa model pembelajaran kooperatif tipe STAD adalah metode yang berfokus pada kegiatan serta interaksi antar siswa agar saling memotivasi serta membantu satu sama lainnya guna memahami materi pembelajaran untuk memperoleh hasil maksimal. Selain itu pendapat Lestari (2016), model pembelajaran kooperatif berpusat pada guru dan juga siswa yang terlibat secara aktif untuk bereksplorasi dan berinvestigasi saat belajar. Siswa juga mampu bekerjasama di dalam kelompoknya dengan tujuan saling bertukar pikiran dan pendapat mengenai materi yang sedang dibahas. 
Widiyastuti, Senjaya \& Lestari (2019) juga menyatakan bahwa salah satu cara untuk membuat siswa mampu menemukan dan membangun pengetahuan yang dimilikinya yaitu melalui penerapan model pembelajaran STAD.

Slavin (Isjoni, 2009) mengemukakan bahwa pembelajaran kooperatif tipe STAD meliputi tahapan penyajian materi, kegiatan kelompok, tes individual, penghitungan skor perkembangan individu, serta pemberian penghargaan kelompok. Prosedur dalam menerapkan model pembelajaran kooperatif tipe STAD yakni: (1) penyampaian materi pembelajaran serta permasalahan oleh guru kepada siswa yang disesuaikan dengan tujuan pencapaian kompetensi dasari; (2) Pemberian soal tes atau kuis yang disusun oleh guru kepada setiap siswa yang dikerjakan secara individu untuk memperoleh skor awal; (3) Pembentukan kelompok siswa yang heterogen oleh guru dimana setiap kelompok berisi 45 orang siswa; (4) guru mempersiapkan bahan ajar sesuai dengan materi yang diajarkan kemudian diberikan kepada siswa untuk didiskusikan bersama di dalam kelompok dalam rangka pencapaian kompetensi dasar; (5) guru bertindak sebagai fasilitator bagi siswa untuk menyusun rangkuman, selanjutnya guru memberikan pengarahan serta penegasan tentang materi ajar yang telah diajarkan; (6) guru menugaskan siswa untuk menyelesaikan soal tes atau kuis yang dikerjakan secara individu; dan (7) guru memberikan penghargaan kepada kelompok berdasarkan kepada hasil perolehan nilai (Daryanto, 2012).

Rendahnya minat belajar siswa yang mengakibatkan rendahnya hasil belajar siswa berdasarkan fakta-fakta dan hasil observasi awal yang telah dipaparkan sebelumnya membuat penulis untuk berupaya mengatasi permasalahan tersebut. Beberapa teori yang telah dipaparkan juga menimbulkan dugaan bahwa minat dan hasil belajar siswa dapat ditingkatkan melalui model STAD. Jadi, penulis menganggap penting untuk melaksanakan penelitian dengan judul Peningkatan Minat dan Hasil Belajar Matematika Siswa dengan Penggunaan Model Pembelajaran Kooperatif Tipe STAD.

\section{METODE PENELITIAN}

Penelitian ini adalah Penelitian Tindakan Kelas (PTK) yang terdiri atas 2 Siklus. Penelitian Tindakan Kelas (PTK) ini dilaksanakan saat semester ganjil tahun ajaran 2019/2020 selama 2 bulan mulai dari tahap persiapan sampai dengan tahap penulisan laporan. Rahmi, Zamista, \& Saputra, (2019) menyatakan bahwa Penelitian Tindakan Kelas (PTK) merupakan salah satu solusi dalam memaksimalkan pelaksanaan pembelajaran sebab PTK memiliki kepekaan dan sensitivitas terhadap prestasi belajar siswa, termasuk 
minat dan hasil belajar siswa. Hal tersebut menjadi salah satu dasar penulis untuk memilih PTK sebagai metode penelitian ini.

Penelitian ini dilaksanakan di salah satu SD di Kecamatan Rimba Sekampung. Selain berdasarkan hasil observasi awal yang telah dipaparkan sebelumnya, pemilihan lokasi penelitian ini diperkuat dengan pernyataan Rahmi, Saputra, Desriati \& Fatmawati (2020) yaitu siswa SD pada salah satu Kecamatan Rimba sekampung memiliki kemampuan berhitung yang rendah. Hal tersebut juga menjadi pedoman penulis untuk melakukan penelitian pada materi Perkalian dan Pembagian.

Peneliti memilih satu kelas untuk digunakan sebagai perwakilan dalam subyek penelitian. Peneliti memilih kelas III SD di salah satu Kecamatan Rimba Sekampung sebagai subyek dari jumlah 3 kelas yang ada. Jumlah siswa tersebut adalah 24 orang dimana siswa laki-laki berjumlah 13 orang dan siswa perempuan berjumlah 11 orang sebagai sampel dalam penelitian terhadap minat juga hasil belajar siswa melalui penerapan model pembelajaran koorperatif tipe STAD. Peneliti memilih kelas tersebut karena dengan mempertimbangkan hasil observasi dari pra-tindakan masih banyak siswa yang belum tuntas dalam pembelajaran Matematika.

Penelitian Tindakan Kelas ini menggunakan model Kurt Lewin dimana 1 Siklus terdiri dari perencanaan (planning), tindakan (acting), observasi (observation), serta refleksi (reflection) (Suci, Rosyidah, Asitah, Aini, Murni, Anam \& Kuraesin., 2018). Dalam pelaksanaan PTK ini peneliti menggunakan kolaborasi dengan wali kelas III dari kelas lainnya di sekolah yang sama. Adapun Siklus spiral tahapan penelitian PTK ini dapat dilihat pada Gambar 1 berikut ini:

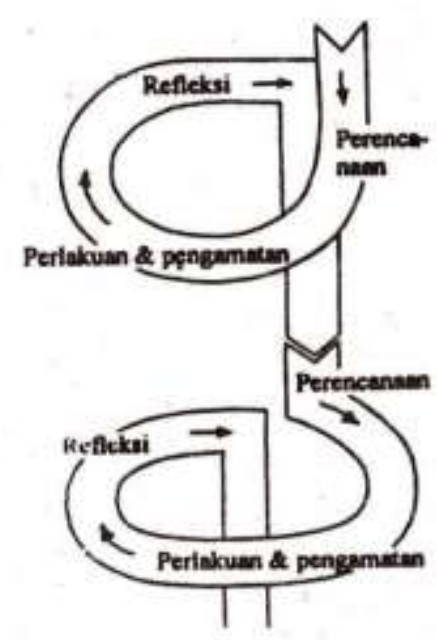

Gambar 1. Tahapan Penelitian

(Kemmis \& McTaggart, 1997) 
Perencanaan adalah penyusunan rumusan masalah, tujuan penelitian serta menyusun rencana tindakan serta alat pengumpul data penelitian serta perangkat pembelajaran. Perlakuan serta pengamatan merupakan hal-hal yang dilakukan oleh peneliti sebagai upaya dalam meningkatkan minat dan hasil belajar siswa kemudian mengamati dampak dari implementasi model pembelajaran STAD. Refleksi adalah kajian mendalam oleh peneliti dengan cara melihat dan mempertimbangkan hasil serta dampak tindakan yang telah dilakukan. Rancangan/rencana kemudian direvisi berdasarkan hasil refleksi dari Siklus sebelumnya dengan cara menyusun perbaikan perencanaan yang dilaksanakan pada Siklus berikutnya.

Berdasarkan pada jenis penelitian yang dipilih, yaitu Penelitian Tindakan Kelas (PTK), maka penelitian ini menggunakan model penelitian tindakan kelas dari Kemmis dan Taggart (dalam Arikunto, 2010), dengan bentuk spiral dari Siklus yang satu ke Siklus berikutnya. Penelitian ini dilaksanakan sebanyak 2 Siklus dimana masing-masing sikus terdiri dari dua pertemuan serta setiap Siklus berdasarkan kepada materi dan tujuan pembelajaran sesuai dengan kurikulum, khususnya pada materi perkalian dan pembagian. Setiap Siklus terdiri atas planning (rencana), action (tindakan), observation (pengamatan), dan reflection (refleksi). Tahapan perencanaan di Siklus berikutnya merupakan tahapan perencanaan yang telah direvisi, tindakan, pengamatan, dan refleksi. Langkah penelitian yang dilakukan oleh peneliti dalam memperbaiki minat dan hasil belajar matematika dengan menggunakan model pembelajaran STAD terdiri atas prosedur penelitian Siklus I dan prosedur penelitian Siklus II dimana setiap prosedur terdiri dari perencanaan, tindakan, pengamatan serta refleksi.

Pada tahap perencanaan Siklus I, peneliti menyusun Rencana Pelaksanaan Pembelajaran (RPP) agar tindakan dalam penelitian dapat berlangsung dengan baik. Peneliti juga memilih dan meilah bahan rujukan yang relevan dengan tahap-tahap Penelitian Tindakan Kelas (PTK). Pada tahap tindakan, peneliti menggunakan model pembelajaran STAD sementara itu teman sejawat yang sebagai kolaborator mengamati partisipasi dan kegiatan siswa pada saat mengikuti kegiatan belajar-mengajar. Melalui observasi ini peneliti dapat mengetahui sejauh mana mode pembelajaran STAD dapat diterapkan dalam memberikan petunjuk perbaikan untuk pemberian tindakan selanjutnya. Refleksi merupakan hasil dari pengamatan dan catatan-catatan hasil evaluasi dalam proses penelitian yang menjadi pedoman dalam menyusun perencanaan tindakan untuk pertemuan selanjutnya sedemikian sehingga dapat terlaksana dengan baik serta mampu menghasilkan 
peningkatan minat dan hasil belajar siswa yang lebih baik lagi pada pertemuan selanjutnya yaitu Siklus ke II.

Prosedur penelitian pada Siklus II juga diawali dengan tahap perencanaan, tindakan, pengamatan dan refleksi. Perbedaan prosedur penelitian Siklus II dengan Siklus I terletak pada tahap tindakan. Peneliti sebagai guru melaksanakan pembelajaran dengan menggunakan model STAD yang dilengkapi dengan tindakan-tindakan yang dianggap kurang pada Siklus I sedemikian sehingga penelitian berhenti pada Siklus II berdasarkan kepada hasil refleksi Siklus II. Siklus berhenti sebab hasil ketuntasan pembelajaran di atas $75 \%$.

Penelitian ini menggunakan dua cara teknik pengumpulan data, yaitu tes yang berupa tes hasil belajar dan non-tes yang berupa angket/kuesioner minat belajar dan observasi. Tes hasil belajar berisi soal-soal yang berkaitan dengan materi pembelajaran sebagai evaluasi hasil belajar kepada siswa. Alat pengumpulan data minat dan hasil belajar siswa pada penelitian tindakan kelas ini terdiri atas tes hasil belajar siswa, pengamatan (observasi) serta kuesioner minat belajar siswa sebagaimana yang telah dipaparkan sebelumnya. Seluruh instrumen tes juga non-tes telah dilakukan analisis kelayakan instrumen sehingga sudah valid dan realiabel. Teknik analisa data yang dipilih oleh peneliti dalam rangka pengolahan data-data hasil penelitian dilakukan dengan tujuan supaya mempermudan peneliti dalam membaca dan memahami data hasil penelitian. Peneliti menggunakan tehnik analisis data kuantitatif

Data yang diperoleh peneliti melalui Tes Hasil Belajar siswa selanjutnya dianalisis dengan teknik analisis data kuantitatif. Analisis data kuantitatif dilakukan dengan menghitung nilai rata-rata siswa. Analisis data kuantitatif ini dilaksanakan setiap akhir dari satu Siklus. Dengan demikian, analisis data kuantitatif akan menjadi refleksi pada Siklus selanjutnya. Setelah menghitung jumlah dan rata-rata siswa, langkah selanjutnya adalah menghitung persentase siswa yang telah mencapai KKM (Kriteria Ketuntasan Minimal). Pencapaian suatu proses pembelajaran dikatakan berhasil apabila hasil ketuntasan pembelajaran di atas $75 \%$.

\section{HASIL DAN PEMBAHASAN}

Hasil penelitian ini telah dilaksanakan dengan menerapkan model pembelajaran kooperatif tipe STAD mencakup Siklus I dan Siklus II yang mana tiap-tiap Siklus dilaksanakan sebanyak dua pertemuan. Data hasil observasi terhadap aktivitas peneliti sebagai guru yang telah diamati oleh kolaborator pada Siklus I yaitu 82,50 pada kategori 
baik yang mencapai peningkatan menjadi 92,50 pada kategori sangat baik di Siklus II. Jadi hasil pengamatan atau observasi dalam proses pembelajaran pada Siklus II dihentikan karena sudah mencapai hasil yang diinginkan dalam penelitian sehingga proses pembelajaran dianggap sudah termasuk kedalam kategori sangat baik.

Berikut ini hasil pengamatan yang telah dilaksanakan oleh kolaborator dalam proses pembelajaran di Siklus I dan Siklus II terhadap minat belajar siswa:

\section{Tabel 1. Hasil Pengamatan terhadap Minat Belajar Siswa}

\begin{tabular}{ccc}
\hline Indikator & Siklus I & Siklus II \\
\hline Kekompakan & 79 & 82 \\
Partisipasi & 85 & 85 \\
Keaktifan & 54 & 73 \\
Tanggung Jawab & 83 & 86 \\
Rata-Rata & $\mathbf{7 8 , 4}$ & $\mathbf{8 4 , 9}$ \\
Kategori & Baik & Baik \\
\hline
\end{tabular}

Dari Tabel 1 di atas nampak bahwa pada skor rerata kekompakan siswa sudah baik, partisipasi siswa juga baik, tetapi dalam keaktifan masih kurang dan pada aspek tanggung jawab siswa sudah baik. Skor dari aspek secara keseluruhan adalah 78,4 sudah masuk kedalam kategori baik. Data minat belajar siswa pada Siklus I yang mencakup pertemuan pertama dan kedua diambil melalui penggunaan angket minat belajar yang diisi oleh siswa di akhir Siklus I pada pertemuan kedua. Peneliti dibantu oleh teman sejawat dalam mengamati proses belajar-mengajar di dalam kelas.

Hasil pengamatan peneliti, minat belajar siswa pada saat mengikuti proses belajarmengajar dengan menggunakan model pembelajaran STAD masih belum terlihat. Terdapat sejumlah siswa yang membuat kekacauan di kelas serta tidak mengikuti pembelajaran dengan baik. Siswa masih enggan memberikan pertanyaan kepada guru terkait materi yang sedang diajarkan oleh guru. Pada saat kegiatan diskusi kelompok, masih ada siswa yang terlihat pasif. Siswa tersebut cenderung diam dalam kegiatan diskusi dan pada kahirnya memancing keributan di dalam kekelompoknya juga dengan kelompok lainnya.

Beberapa siswa tampak tidak aktif dalam bertanya ataupun menjawab pertanyaan pada sesi tanya-jawab. Di dalam setiap kelompok, rata-rata hanya dua orang siswa yang aktif dalam sesi tanya-jawab. Namun, tingkat kemampuan siswa dalam memahami materi ajar pada pertemuan pertama ini mengalami peningkatan. Kemampuan pemahaman siswa muncul karena adanya minat belajar siswa. Temuan ini menunjukkan bahwa siswa telah mangalami peningkatan minat belajar melalui penerapan model pembelajaran kooperatif 
tipe STAD. Minat belajar siswa pada Siklus I ini diukur dengan menggunakan kuesioner minat belajar.

Hasil observasi dari Siklus I sebagaimana yang telah dipaparkan sebelumnya sudah sangat sesuai dengan tahap persiapan yang dilakukan oleh peneliti sebelum pelaksanaan penelitian. Hasil pengamatan peneliti terhadap minat siswa saat belajar adalah tampak siswa telah mau menyimak penjelasan materi oleh guru namun masih terdapat siswa yang membuat keributan serta enggan menyimak setiap materi yang disampaikan oleh guru. Siswa tersebut mayoritas merupakan siswa dengan jenis kelamin laki-laki. Mayoritas siswa telah memiliki kemampuan dalam menyelesaikan permasalahan yang diberikan kemudian bersedia mengemukakan pendapatnya di depan kelas. Siswa juga telah bersedia untuk memberikan pertanyaan terkait materi yang belum dipahami serta telah berssemangat dalam diskusi kelompok sebab siswa telah betah berada di dalam kelompok dan kegiatan diskusi kelompok.

Dari Tabel 1 di atas terlihat bahwa seluruh aktivitas siswa yaitu kekompakan, partisipasi, keaktifan dan tanggung jawab yang merupakan indikator minat belajar siswa selama proses pembelajaran mengalami peningkatan. Hal tersebut terlihat dari aspek kekompakan, partisipasi, tanggung jawab dan khususnya keaktifan mengalami peningkatan. Siswa yang pada awalnya tidak terlalu kompak berusaha untuk mengerjakan bersama-sama untuk mendapatkan penghargaan jika kelompoknya memiliki nilai yang tinggi.

Hasil observasi dari Siklus II telah bersesuaian dengan yang telah dipersiapkan oleh peneliti. Hasil pengamatan peneliti terhadap minat siswa saat belajar adalah siswa telah mau menyimak materi yang dijelaskan oleh guru. Siswa telah memiliki kemampuan untuk menyelesaikan permasalahan kemudian bersedia untuk mengemukakan hasil kerjanya di depan kelas tanpa ditunjuk oleh guru. Pada saat kegiatan diskusi kelompok, siswa telah memiliki inisiatif untuk memberikan pertanyaan kepada guru. Siswa juga telah merasa nyaman berada di dalam kelompok dan bersedia melakukan diskusi bersama teman sekelompoknya. Saat pelaksanaan aktivitas tanya-jawab, siswa telah tampak berperan aktif terutama saat menjawab permasalahan yang diberikan dan juga siswa tampak antusias dalam memberikan tanggapan. Siswa yang pada awalnya merasa malu untuk mempresentasikan hasil kerjanya, kini tampak semakin percaya diri dan aktif. Dari perhitungan jumlah rata-rata seluruh aspek, maka sesuai dengan Tabel 1, hasil pengamatan terhadap minat belajar siswa mengalami peningkatan menjadi 84,9 dengan kategori baik. 
Untuk memudahkan pembahasan dan mengetahui perkembangan hasil belajar, maka hasil belajar siswa disajikan dari data awal, Siklus I dan Siklus II pada Tabel 2 sebagai berikut:

Tabel 2. Deskripsi Hasil Belajar Siswa pada Siklus I dan Siklus II

\begin{tabular}{ccccccccccc}
\hline No & $\begin{array}{c}\text { Rent } \\
\text { ang }\end{array}$ & \multicolumn{2}{c}{ Jumlah Siswa } & \multicolumn{2}{c}{ Rata-Rata (\%) } & \multicolumn{2}{c}{ Rata-Rata Nilai } \\
& Nilai & Awal & $\begin{array}{c}\text { Siklus } \\
\text { I }\end{array}$ & $\begin{array}{c}\text { Siklus } \\
\text { II }\end{array}$ & Awal & $\begin{array}{c}\text { Siklus } \\
\text { I }\end{array}$ & $\begin{array}{c}\text { Siklus } \\
\text { II }\end{array}$ & Awal & $\begin{array}{c}\text { Siklus } \\
\text { I }\end{array}$ & $\begin{array}{c}\text { Siklus } \\
\text { II }\end{array}$ \\
\hline 1 & $\geq 75$ & 13 & 18 & 20 & $54,17 \%$ & $75,00 \%$ & $83,33 \%$ & & & \\
2 & $<75$ & 11 & 6 & 4 & $45,83 \%$ & $25,00 \%$ & $16,67 \%$ & $\mathbf{7 0 , 8}$ & $\mathbf{8 2 , 3}$ & $\mathbf{8 6 , 2}$ \\
Jumlah & & 24 Siswa & & & $100 \%$ & & & & \\
\hline
\end{tabular}

Berdasarkan Tabel 1 di atas tampak bahwa peningkatan hasil belajar siswa pada pembelajaran Matematika dengan menerapkan model pembelajaran kooperatif tipe STAD mengalami peningkatan yang signifikan. Berdasarkan jumlah siswa yang tuntas pada data awal adalah 13 orang siswa atau dengan persentase 54,17\% mengalami peningkatan pada Siklus I yaitu 18 orang siswa dengan persentase $75,00 \%$ selanjutnya pada Siklus II mengalami peningkatan lagi menjadi 20 orang siswa atau dengan persentase $83,33 \%$. Jumlah siswa yang tidak tuntas atau di bawah $<75$ mengalami penurunan dari data awal 11 orang siswa atau 45,83\% mengalami penurunan pada Siklus I menjadi 6 orang siswa atau $25,00 \%$ dan pada Siklus II mengalami penurunan kembali menjadi 4 orang siswa atau $16,67 \%$.

Selanjutnya dari Tabel 2 juga terlihat rata-rata akhir penilaian pembelajaran mengalami peningkatan. Dari data awal terlihat hasil belajar siswa mendapatkan rata-rata nilai sebesar 70,8 mengalami peingkatan pada Siklus I menjadi 82,3 dan pada Siklus II mengalami peningkatan menjadi 86,20. Dari hasil evaluasi belajar pada Siklus II dengan rata-rata 86,20 atau persentase ketuntasannya adalah $75 \%$ sudah mencukupi dari minimal hasil klasikal yaitu 75\% maka penelitian ini berhenti pada Siklus II.

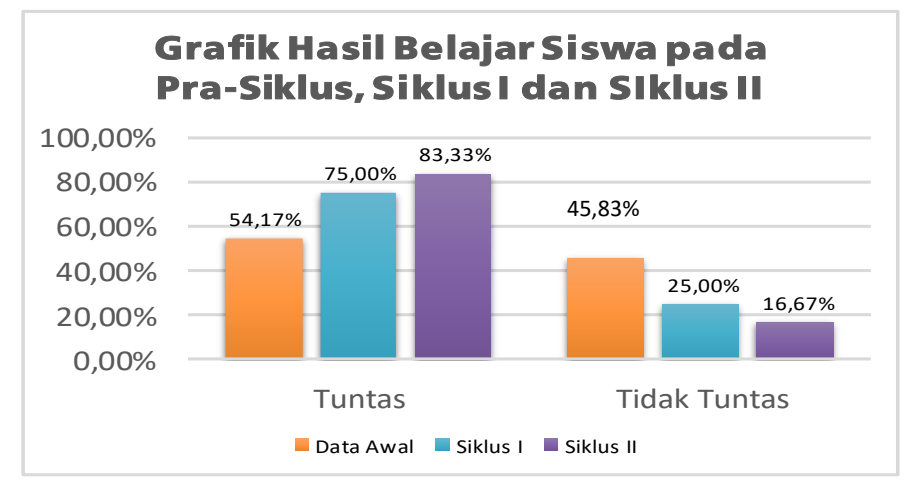

Gambar 2 Diagram Batang Hasil Belajar Siswa 
Melalui Gambar 2 di atas terlihat jelas hasil belajar siswa dalam pembelajaran Matematika dengan menerapkan model pembelajaran koorperatif tipe STAD mampu meningkatkan dan memperbaiki hasil belajar Matematika pada siswa kelas III SD tempat penelitian. Terlihat jelas jumlah siswa yang tuntas pada data awal yaitu 54,17\% naik menjadi 75,00\% dan pada Siklus II semakin meningkat menjadi 83,33\% siswa yang tuntas pembelajaran. Selanjutnya untuk siswa yang tidak tuntas mengalami penurunan dari data awal mendapatkan persentase $45,83 \%$ menjadi $25,00 \%$ dan semakin mengalami penurunan pada Siklus II menjadi 16,67\%.

Hasil analisis kuantitatif di atas berbesuaian dengan hasil kualitatif berdasarkan instrumen non-tes yang telah diberikan, yaitu lembar observasi. Pada tahap perencanaan di Siklus I, peneliti mempersiapkan hal-hal yang diperlukan dan yang akan digunakan pada penelitan sebagai pedoman pada tahap pelaksanaan tindakan. Pada tahap perencanaan, dilakukan penyusunan Rencana Pelaksanaan Pembelajaran (RPP), mempersiapkan bahan pembelajaran yaitu materi pembelajaran Matematika mengenai materi Perkalian, mempersiapkan media pembelajaran berupa gambar, menyiapkan lembar observasi terhadap guru dan siswa sebagai bahan pertimbangan refleksi untuk Siklus berikutnya, menyusun soal tes yang didasarkan pada materi yang telah disampaikan yang akan ditugaskan setelah siswa selesai mengerjakan LKS dan mempresentasikannya di depan kelas. Guru juga membuat instrumen penilaian (Tes Hasil Belajar I) yang ditugaskan kepada siswa di akhir Siklus. Pelaksanaan proses pembelajaran dalam upaya mencapai tujuan pendidikan, harus didasarkan pada perencanaan yang matang hingga menghasilkan tujuan akhir pembelajaran yang diharapkan di seluruh mata pelajaran, termasuk Matematika (Nasution, Pebrianti, Rahmi, 2020).

Pada tahap pelaksanaan, proses pembelajaran dilaksanakan sebanyak dua kali pertemuan dimana alokasi waktu pada tiap pertemuan adalah 2 x 35 menit (2 jp) menyesuakan jam pelajaran di tingkat Sekolah Dasar (SD) tempat penelitian. Pelaksanaan tindakan pada Siklus I adalah siswa memiliki pemahaman terhadap konsep perkalian dengan mengaitkan materi yang telah mereka pelajari sebelumnya, yaitu materi Penjumlahan. Pelaksanaan tindakan ini dilakukan dengan menggunakan model pembelajaran kooperatif tipe STAD dimana kelompok menghasilkan pemahaman bahwa ternyata Perkalian adalah Penjumlahan Berulang.

Selama kegiatan pembelajaran, seluruh siswa tampak antusias dan bersemangat untuk belajar. Siswa tampak menuliskan poin-poin penting yang diperoleh saat belajar kemudian memberikan pertanyaan mengenai materi yang tidak dimengerti. Saat kegiatan 
presentasi kelas selesai, guru memberikan soal tes hasil belajar kepada siswa guna memperoleh skor awal. Setelah siswa berada di dalam kelompok kecil yang berjumlah 4 atau 5 orang, setiap siswa bersama teman kelompoknya tampak memperhatikan media yang telah disediakan guru. Masing-masing kelompok mengerjakan Lembar Kerja Siswa (LKS) yang harus diselesaikan secara bersama-sama dengan teman sekelompoknya. Guru mengamati aktivitas siswa di dalam kelompok dengan cara berkeliling kelas. Guru melaani setiap pertayaan siswa dan membantu siswa yang mengalami kesulitan dalam menginterpretasikan permasalahan yang ada di LKS. Setelah permasalahan selesai dikerjakan, setiap kelompok dipersilahkan utuk mempresentasikan hasil kerjanya di depan kelas. Guru mempersilahkan setiap kelompok secara bergantian ke depan kelas untuk menyajikan hasil diskusinya kemudian mempersilahkan kelompok lainnya memberikan kritik dan saran yang berkaitan dengan hasil presentasi kelompok.

Selama kegiatan pembelajaran berlangsung tampak semua siswa aktif dan juga siswa mampu mengambil simpulan tetang materi yang diajarkan dengan benar. Namun masih terdapat beberapa orang siswa yang tidak terlalu memperdulikan mengenai kegiatan diskusi kelompok. Setelah semua kelompok mempresentasikan hasil diskusi. Guru menugaskan seluruh siswa untuk menyelesaikan soal tes hasil belajar untuk mengetahui sejauh mana tingkat pemahaman siswa saat mengikuti proses pembelajaran. Guru meminta siswa untuk mengumpulkan hasil penyelesaian soal tes tersebut di meja guru. Selanjutnya, guru memberikan kesimpulan dan merangkum materi baik secara tertulis maupun lisan.

Pada kegiatan akhir pembelajaran, guru bersama siswa memberikan kesimpulan terkait materi yang telah diajarkan. Guru menugaskan siswa untuk mempelajari materi yang akan dibahas pada pertemuan berikutnya. Guru bertanya mengenai bagaimana perasaan siswa saat belajar dengan menerapkan model pembelajaran kooperatif tipe STAD. Siswa tampak senang saat belajar dan antusias terhadap materi yang diajarkan oleh guru. Sebelum pembelajaran berakhir, guru memberikan sertifikat sebagai penghagaan kepada kelompok dengan nilai rata-rata hasil belajar tertinggi. Sebelum guru mengakhiri proses pembelajaran, guru memberi peringatan kepada siswa tetang aktivitas yang dilarang saat pergantian jam pelajaran. Selanjutnya, guru meminta siswa untuk mengembalikan kalung nomor yang digunakan oleh siswa pada saat proses pembelajaran. Guru mengakhiri pembelajaran dengan salam.

Berdasarkan pelaksanaan penelitian pada Siklus I, secara keseluruhan penggunaan model pembelajaran STAD sudah dilaksanakan sesuai dengan perencanaan penelitian tindakan kelas. Akhir dari Siklus I ini adalah pemberian soal evaluasi berupa Tes Hasil 
Belajar I pada akhir pertemuan kedua yang berisi materi yang telah dipelajari pada pertemuan pertama dan kedua. Saat proses pembelajaran telah selesai dilaksanakan, peneliti mengamati dan menganalisis hasil tes belajar, data lembar observasi, kritik/saran dari rekan peneliti dan selanjutnya peneliti dibantu kolaborator melakukan refleksi untuk menentukan tindakan apa yang akan dilakukan. Selanjutnya peneliti melakukan evaluasi melalui kegiatan diskusi terkait permasalahan yang terjadi selama proses pembelajaran.

Berdasarkan hasil pengamatan, terdapat beberapa kekurangan dan kelemahan pengelolaan yang terjadi pada Siklus I, antara lain sebagai berikut: (1) ketika guru mengorganisasikan siswa menjadi beberapa kelompok, masih banyak siswa yang menginginkan berada di kelompok lain yang dipilihnya sendiri yang berakibat terdapat beberapa orang siswa yang tidak memiliki kelompok; (2) pada saat kegiatan pembelajaran, masih terdapat beberapa siswa yang tampak tidak serius pada pelaksanaan prosedur belajar mengajar, tampak siswa malah asik bercerita namun ketika guru mendekatinya siswa tersebut tampak mulai serius kembali begitu seterusnya selama proses pembelajaran berlangsung; (3) masih terdapat beberapa orang siswa yang merasa malu dan cenderung pasif saat ditunjuk mempresentasikan hasil pekerjaan kelompok.

Adapun rencana yang dilakukan peneliti untuk memperbaiki kelemahan dan kekurangan yang terjadi terdiri atas beberapa upaya. Sebelum proses pembelajaran dimulai, guru menjelaskan kembali mengenai proses pembelajaran dan membentuk kelompok belajar secara acak. Dalam pembentukan kelompok guru memberikan aturan jika siswa yang tidak ikut bekerja dalam menyelesaikan soal LKS maka siswa tidak mendapatkan nilai. Ketika guru sudah memulai diskusi kelas, guru menjelaskan kembali langkah-langkah kegiatan diskusi dalam setiap kelompok-kelompok kecil di dalam kelas. Untuk kegiatan selanjutnya guru tidak hanya sebagai fasilitator saja, tetapi jika ada siswa yang membuat keributan atau bermain-main maka guru akan mendekati siswa tersebut kemudian memberi peringatan, namun apabila sudah keterlalulan membuat keributan guru akan memberikan hukuman seperti siswa tersebut tidak perlu mengikuti proses pembelajaran. Selanjutnya guru akan memberikan motivasi dan semangat kepada seluruh siswa untuk berani dalam mengemukakan pendapatnya dan mempresentasikan hasil diskusinya ke depan kelas.

Hasil Refleksi terhadap pelaksanaan Siklus I tersebut diperoleh dari pengamatan dan catatan-catatan hasil evaluasi dalam proses penelitian dan menjadi dasar penyusunan rencana tindakan pada pertemuan berikutnya sehingga bisa terlaksana dengan maksimal. 
Rata-rata nilai tes dan ketuntasan belajar belum memenuhi indikator keberhasilan yaitu 75 maka penelitian ini berlanjut ke Siklus II.

Pada Siklus II, peneliti menerapkan tahapan penelitian yang sama dengan Siklus I tetapi untuk hal kekurangan pada Siklus I diperbaiki pada Siklus II. Tahap perencanaan pada Siklus II ini serupa dengan hal-hal yang telah disiapkan di Siklus I. Peneliti menyusun hal-hal yang akan berguna dan dibutuhkan pada penelitian. Peneliti terlebih dahulu menganalisis Kompetensi Dasar (KD), indikator, dan materi pokok penelitian. Kemudian, peneliti menyusun Silabus, Rencana Pelaksanaan Pembelajaran (RPP), media pembelajaran berupa video, Lembar Kerja Siswa (LKS), tes hasil belajar, serta rubrik penskoran.

Pada Siklus II, siswa mempelajari materi Pembagian melalui media yang telah dipersiapkan guru, yaitu berupa video pembelajaran dengan menerapkan model kooperatif tipe STAD. Pada Siklus II tampak seluruh siswa hadir semua. Pada kegiatan awal, guru mengucapkan salam dan membimbing siswa untuk berdo'a sebelum memulai pelajaran. Tampak siswa semua khusyuk dalam berdoa. Setelah berdoa, guru mengecek kehadiran siswa dan melaksanakan apersepsi. Guru bertanya tentang materi pelajaran yang sudah diajarkan pada pertemuan sebelumnya untuk mengembalikan ingatan siswa mengenai materi sebelumnya. Guru mengajak siswa untuk bernyanyi bersama. Judul lagu yang dibawakan yaitu “Ayo Belajar" tetapi menggunakan irama "Menanam Jagung” sebagai pemberian motivasi kepada siswa. Guru melanjutkan dengan menyampaikan tujuan pembelajaran dan manfaat mempelajari materi tersebut. Guru kemudian melakukan kegiatan tanya-jawab dengan siswa untuk mengingatkan siswa kepada materi prasyarat sebelum pembelajaran memasuki kegiatan inti.

Langkah pertama yang dilakukan oleh guru pada kegiatan inti pelajaran adalah menampilkan beberapa gambar mengenai jenis-jenis aturan perkalian yang kemudian dikaitkan dengan materi Pembagian. Selanjutnya, guru membagi siswa ke dalam delapan kelompok secara acak dengan memperhatikan heterogenitas setiap kelompok dimana setiap kelompok terdiri atas empat sampai lima orang siswa. Guru mengatur kelompok tersebut berdasarkan daftar pemilihan anggota kelompok yang telah disusun sebelumnya. Tahapan selanjutnya adalah masing-masing siswa duduk bersama teman kelompoknya. Masing-masing kelompok mmperoleh Lembar Kerja Siswa (LKS) yang kemudian didiskusikan dan diselesaikan secara bersama-sama dengan teman kelompoknya. Guru mengamati aktivitas siswa di dalam kelompok dengan cara berkeliling kelas sambil memberikan scaffolding jika dibutuhkan. Guru membimbing siswa yang mengalami 
kesulitan dalam menyelesaikan permasalahan terdapat pada LKS. Setelah seluruh kelompok telah menyelesaikan LKS, guru mempersilahkan masing-masing kelompok untuk mempresentasikan hasil diskusinya di depan kelas. Seluruh kelompok diwajibkan untuk tampil di depan kelas kemudian meminta kelompok lain untuk memberikan kritik dan saran hasil kerja kelompok yang presentasi. Selanjutnya, guru dan siswa melakukan tanya-jawab tentang materi yang belum dipahami. Guru kemudian meluruskan pemahaman siswa yang kurang tepat melalui pemberian penguatan kepada siswa.

Guru bersama siswa membuta kesimpulan tentang materi yang telah dipelajari pada kegiatan akhir. Guru menugaskan siswa untuk belajar di rumah terkait materi yang akan dipelajari pada pertemuan berikutnya. Siswa diminta untuk melakukan refleksi tentang pengalaman mereka pada saat belajar menggunakan model pembelajaran kooperatif tipe STAD. Sebelum proses pembelajaran berakhir, guru memberikan penghargaan kepada kelompok dengan nilai rata-rata hasil belajar tertinggi. Sebelum guru mengakhiri pembelajaran dengan Salam, guru menyampaikan aktivitas yang tidak diizinkan selama pergantian jam pelajaran.

Refleksi Sikllus II diperoleh berdasarkan hasil observasi serta catatan-catatan hasil refleksi dan evaluasi dalam proses penelitian yang menjadi dasar penyusunan rencana tindakan sehingga pembelajaran pada pertemuan berikutnya berjalan dengan lancar. Pembelajaran di Siklus II pertemuan pertama dan kedua secara umum sudah terlaksana dengan maksimal. Guru telah menjelaskan langkah-langkah model pembelajaran koorperatif tipe STAD serta menjalankannya dengan benar. Seluruh langkah pembelajaran dalam skenario pembelajaran telah dilaksanakan dan tidak ada yang terlewatkan. Siswa juga sudah tidak merasa ragu untuk mempresentasikan hasil diskusinya di depan kelas. Pada kegiatan diskusi siswa sangat antusias dalam mengerjakan LKS. Kegiatan dalam pembelajaran Matematika menerapkan model pembelajaran kooperatif tipe STAD mampu memberikan peningkatan serta perbaikan pada pembelajaran Matematika bagi siswa kelas III SD. Rata-rata nilai tes dan ketuntasan belajar telah memenuhi indikator keberhasilan yaitu 75 maka penelitian ini dihentikan pada Siklus II.

Terdapat 3 perbedaan tindakan antara Siklus I dan Siklus II. Pertama, guru menggunakan teknik bernyanyi untuk memotivasi siswa pada Siklus II yang tidak terjadi di Siklus I. Selanjutnya, pada Siklus I guru memberikan media gambar yang didiskusikan bersama di dalam kelompok. Sementara pada Siklus II, guru menggunakan media audio visual untuk mempermudah kegiatan bernyanyi di dalam kelompok. Penggunaan media menimbulkan daya tarik dan memberikan pengalaman dramatis bagi siswa sehingga 
berkesan dan membekas dalam pikiran siswa serta mempermudah guru dalam penyampaian proses pembelajaran (Nasution \& Siregar, 2019; Sari, Nasution dan Laswadi, 2020). Terakhir, pada Siklus II guru mengganti anggota kelompok sebab masih ada kelompok yang homogen pada Siklus I.

Berdasarkan hasil penelitian di atas tampak bahwa terdapat peningkatan hasil belajar siswa yang tampak melalui peningkatan nilai rata-rata tes siswa dan ketuntasan belajar siswa. Jadi, hasil penelitian tersebut membuktikan hipotesis yaitu penerapan model pembelajaran koorperatif tipe STAD dapat meningkatkan hasil belajar pada mata pelajaran Matematika. Selain itu, model pembelajaran koorperatif tipe STAD juga dapat menciptakan situasi pembelajaran yang baru dan mampu menumbuhkan motivasi belajar siswa saat belajar sehinga prestasi belajar mereka dapat meningkat.

Dosen sebagai peneliti tindakan kelas juga telah dilaksanakan oleh Nasution \& Lubis (2019) pada penggunaan model pembelajaran kooperatif tipe Jigsaw yang dapat meningkatkan hasil belajar siswa. Hasil penelitian tindakan kelas lain oleh Rahmi, Syafweny, Susilawaty \& Fatmawati (2020) yang menghasilkan peningkatan hasil belajar siswa kelas 3 SD dengan model pembelajaran Problem Based Learnig (PBL). Hal tersebut berimplikasi bahwa penelitian ini juga dapat dilanjutkan dengan penerapan model pembelajaran lainnya.

\section{KESIMPULAN}

Dari hasil penelitian dan pembahasan bisa disimpulkan bahwa dengan penggunaan model pembelajaran Student Teams Achieve Division (STAD) dalam pembelajaran matematika pada materi perkalian dan pembagian maka dapat meningkatkan minat dan hasil belajar pada siswa kelas III SD. Hal tersebut diperoleh berdasarkan peningkatan nilai rata-rata minat belajar siswa dari Siklus I ke Siklus II dengan kategori baik. Kemudian nilai rata-rata hasil belajar dan persentase ketuntasan belajar siswa mengalami peningkatan dari Pra-Siklus, Siklus I dan Siklus II. Hal tesebut menunjukkan bahwa pembelajaran matematika dengan menggunakan model STAD sudah dilaksanakan dengan baik dan sudah sesuai sebagaimana yang diharapkan dan mampu meningkatan minat dan hasil belajar siswa.

\section{DAFTAR PUSTAKA}

Arikunto, S. (2010). Prosedur Penelitian Suatu Pendekatan PraktikJakarta: Rineka Cipta. Daryanto, M. R. (2012). Model Pembelajaran Inovatif. Yogyakarta: Gava Media. 
30 Peningkatan Minat Dan Hasil Belajar Matematika Siswa dengan Penggunaan Model Pembelajaran Kooperatif Tipe Sudent Teams Achievement Division

Esminarto, E., Sukowati, S., Suryowati, N., \& Anam, K. (2016). Implementasi Model Stad dalam Meningkatkan Hasil Belajar Siwa. BRILIANT: Jurnal Riset dan Konseptual, $1(1), 16-23$.

Handayani, R. D., Nandang, N., \& Lestari, W. D. (2018). Perbandingan Kemampuan Komunikasi Matematis Siswa antara yang Menggunakan Metode Pembelajaran Talking Stick dan Think Talk Write. Mathline: Jurnal Matematika dan Pendidikan Matematika, 3(2), 151-158.

Hamalik. (2009). Proses Belajar Mengajar. Bandung : Bumi Aksara.

Hosnan. (2014). Pendekatan Saintifik dan Kontekstual dalam Pembelajaran Abad 21. Jakarta: PT Ghalia Indonesia.

Indonesia, P. R. (2013). Peraturan Pemerintah Nomor 32 Tahun 2013 Tentang Perubahan Atas Peraturan Pemerintah Nomor 19 Tahun 2005 Tentang Standar Nasional Pendidikan. Jakarta: Presiden Republik Indonesia.

Isjoni, H. (2009). Pembelajaran Kooperatif Meningkatkan Kecerdasan Komunikasi Antar Peserta Didik. Yogyakarta: Pustaka Pelajar.

Kemmis, S. \& McTaggart, R. (1997). The action research planner, Deaken University, Victoria.

Lestari, W. D. (2016). Penerapan Pembelajaran Kooperatif Tipe Group Investigation Berbantuan Proyek Terhadap Kemampuan Pemecahan Masalah Matematis Siswa SMP. JMPM: Jurnal Matematika dan Pendidikan Matematika, 1(2), 154-164.

Lestari, W. D., Aisah, L. S., \& Nurafifah, L. (2020, October). What is the relationship between self-regulated learning and students' mathematical understanding in online lectures during the covid-19 pandemic?. In Journal of Physics: Conference Series (Vol. 1657, No. 1, p. 012065). IOP Publishing.

Nasution, E. Y. P. (2015). Meningkatkan kemampuan pemahamnan matematis siswa melalui pembelajaran matematika berbantuan geogebra. Logaritma: Jurnal Ilmuilmu Pendidikan dan Sains, 3(02), 55-69. - (2016). Analisis terhadap Disposisi Matematis Siswa SMK pada Pembelajaran Matematika. Logaritma: Jurnal Ilmu-ilmu Pendidikan dan Sains, 4(01), 77-95.

Nasution, E. Y. P., \& Lubis, F. H. (2019). Meningkatkan Aktivitas dan Hasil Belajar Siswa melalui Model Pembelajaran Kooperatif Tipe Jigsaw Berbasis Algebrator. PYTHAGORAS: Jurnal Program Studi Pendidikan Matematika, 8(2), 82-92. 
Nasution, E. Y. P., Pebrianti, D., \& Putri, R. (2020). Analisis Terhadap Disposisi Berpikir Kritis Siswa Jurusan IPS Pada Pembelajaran Matematika. Mathline: Jurnal Matematika dan Pendidikan Matematika, 5(1), 61-76.

Nasution, E. Y. P., \& Siregar, N. F. (2019). Pengembangan Media Pembelajaran Berbasis Prezi. Tarbawi: Jurnal Ilmu Pendidikan, 15(02), 205-221.

Pangestu, A. D., Samparadja, H., \& Tiya, K. (2015). Pengaruh Minat terhadap Hasil Belajar Matematika Siswa SMA Negeri 1 Uluiwoi Kabupaten Kolaka Timur. Jurnal Penelitian Pendidikan Matematika, 3(2), 17-26.

Pendidikan, D. D. P., \& Kebudayaan, K. B. B. I. (2002). Jakarta. Kencana Perdana Media Group.

Purwandari, A., \& Wahyuningtyas, D. T. (2017). Eksperimen Model Pembelajaran Teams Games Tournament (TGT) Berbantuan Media Keranjang Biji-Bijian terhadap Hasil Belajar Materi Perkalian dan Pembagian Siswa Kelas II SDN Saptorenggo 02. Jurnal Ilmiah Sekolah Dasar, 1(3), 163-170.

Rahmi, H., Zamista, A. A., \& Saputra, J. (2019). Pelatihan Penelitian Tindakan Kelas Kepada Guru SDN 001 Rimba Sekampung Dumai. Madani: Indonesian Journal of Civil Society, 1(1), 29-33.

Rahmi, H., Saputra, J., Desriati, W., \& Fatmawati, F. (2020). Peningkatan Kemampuan Berhitung Siswa Kelas II Dengan Menggunakan Sempoa Aritmatika Di Sekolah Dasar. Madani: Indonesian Journal of Civil Society, 2(2), 50-56.

Rahmi, H., Syafweny, E., Susilawaty, S., \& Fatmawati, F. (2020). Peningkatan Hasil Belajar Matematika Siswa Sd Dengan Menggunakan Model Pembelajaran Problem Based Learning (PBL). Nabla Dewantara: Jurnal Pendidikan Matematika, 5(2), 4760 .

Sari, S. A., Nasution, E. Y. P., \& Laswadi, L. (2020). Penerapan Model Student Facilitator and Explaining (SFE) dengan Media Poster untuk Meningkatkan Kemampuan Representasi Matematis Siswa. Logaritma: Jurnal Ilmu-ilmu Pendidikan dan Sains, 8(01), 105-118.

Slameto. (2003). Belajar dan Faktor-faktor yang Mempengaruhinya. Jakarta: PT Rineka Cipta.

Suci, S. H. A., Rosyidah, E., Asitah, N., Aini, N., Murni, A. W., Anam, F., ... \& Kuraesin, A. D. (2018, November). Learning from Picture and Picture Action Research: Enhancement of Counting Ability on Division of Numbers for Primary School 
32 Peningkatan Minat Dan Hasil Belajar Matematika Siswa dengan Penggunaan Model Pembelajaran Kooperatif Tipe Sudent Teams Achievement Division

Students. In Journal of Physics: Conference Series (Vol. 1114, No. 1, p. 012044).

IOP Publishing.

Susanto, A. (2013). Teori Belajar dan Pembelajaran di Sekolah Dasar. Jakarta: Penanda Media Group.

Widiyastuti, N., Senjaya, A. J., \& Lestari, W. D. (2019). Perbedaan Kemampuan Koneksi Matematis pada Materi Segitiga Berdasarkan Jenis Apersepsi Alfa Zone dan Mathematical Habits of Mind Level Pada Model Pembelajaran Kooperatif Tipe STAD. Mathline: Jurnal Matematika dan Pendidikan Matematika, 4(1), 41-48.

Winkel, W. S. (2004). Psikologi Pengajaran. Terjemahan Teori Setiawan. Jakarta: Media Abadi. 